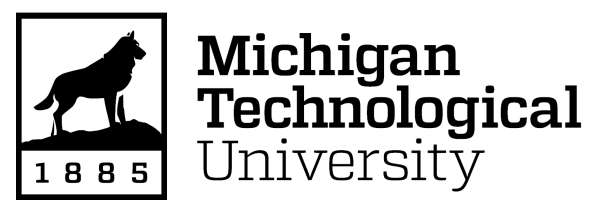

Michigan Technological University Digital Commons@ Michigan Tech

5-31-1967

\title{
Community Relationships and Population Dynamics of Terrestrial Mammals of Isle Royale, Lake Superior, 1966-1967
}

Wendel J. Johnson

Purdue University

Michael L. Wolfe Jr.

Purdue University

Durward L. Allen

Purdue University

Follow this and additional works at: https://digitalcommons.mtu.edu/wolf-annualreports

\section{Recommended Citation}

Johnson, Wendel J.; Wolfe, Michael L. Jr.; and Allen, Durward L., "Community Relationships and Population Dynamics of Terrestrial Mammals of Isle Royale, Lake Superior, 1966-1967" (1967). Ecological Studies of Wolves on Isle Royale. 55.

10.37099/mtu.dc.wolf-annualreports/1966-1967 
COMMNITY RELATIONSHIPS AND POPULATION DYNAMICS

OF TERRESTRIAL MAMMALS ON ISLE ROYALE, LAKE SUPERIOR*

First Annual Report

1966-67

by

Wendel J. Johnson, Graduate Research Assistant

Michael L. Wolfe, Jr., Research Associate

Durward L. Allen, Professor of Wildlife Ecology

Department of Forestry and Conservation Purdue University

Lafayette, Indiana 47907

31 May 1967

* Recelving princlpal support during the current year from the National

Sclence Foundation (GB-5124) and the Netional Park Service.

NOT FOR PUBLICATION 
The past year was the ninth in the investigation of Isle Royale mammals carried on by Purdue University and the National Park Service. It is the inftial year of work in another phase of the study, which is under our fourth grant in Environmental Biology from the National Sclence Foundation.

The last annual report terminated Peter A. Jordan's post-doctoral research on the moose and its relationships; it carried the work into June, 1966. Jordan stayed with the project on the campus through August, working up Information for publication, after which he joined the staff at Yale. He has several papers in preparation.

In August, 1966, L. David Mech's monograph on "The Wolves of Isle Royale" was published as the Seventh National Parks Fauna (Supt. Doc., Washington, D. C., 210 pp). This publication, long delayed in the Government Printing office, was essentially Mech's doctoral thesis and gave complete coverage to the first three years of this program. Likewise in August 1966, Jordan and Allen took part in a symposium on wolves at the American Institute of Biological Sciences meeting at College Park, Maryland. The paper, authored by Jordan, Shelton, and Allen, and entitled "Numbers, turnover, and sncial structure of the Iole Royale Wolf Population," was published in American Zoologist for May, 1967.

Wendel Johnson came to Purdue from Michigan State University in September, 1965, and began course work for the $\mathrm{Ph}$. D. A summer in the field in 1966, and the winter period following (February-March, 1967) were devoted largely to experimentation with various trapping and other techniques. Johnson's quantitative study of the smaller mammals of Isle Royale poses complex inventory problems. These must be worked out on a statistically satisfactory basis through fairly extensive trials of live-trapping and other techniques. The duration of this segment of the study is not now predictable.

Research on wolf-moose relationships is a long-term phase of this program, since the accumulation of records on such long-lived animals is relatively slow. It is being continued as a post-doctoral project by Michael Wolfe, who finished his $\mathrm{Ph}$. D. at the University of Göttingen, West Germany, in December, 1966. He joined the Purdue research team on Isle Royale in February, 1967. Since last year's report was issued as of July and there was some time lapse in field work between Jordan and Wolfe, little was added to our knowledge of the moose and wolf during last summer. The winter period was productive as usual.

\section{Work Schedule, 1966-67}

Johnson was on the island from the second week of June through September. Contributions to the work for ten weeks at this season were made by undergraduates John A. Coble and William A. Knauer, who were supported by the department's Undergraduate Research Participation program of the National Science Foundation (GY-342). 
Winter field work began on 2 February, with a flight in two planes (as usual) from the Eveleth-Virginia Airport, Minnesota. The party consisted of Allen, Johnson, field pilot Donald E. Murray, and Richard W. Igo, maintenance supervisor of Isle Royale National Park. Igo was followed by others of the park staff who interchanged at 10-day to 2-week intervals: C. Newton Sikes, Zeb $V$. MoKinney, Robert W. Rogers, and Warner Forsell. Michael Wolfe arrived on February 11, and Allen left on March 2. Johnson, Wolfe, and Murray closed the camp on 21 March. Continuing the practice of former years, connection flights were furnished by William J. Martila in a Cessna 180 .

\section{Studies of the Terrestrial Small Mammal Community}

Previous biological investigations of Isle Royale have given the smaller mammals only cursory treatment. As indicated by Mech's review (1966, Nat. Parks Fauna 7), there never has been an intensive study of any of these species in the island ecosystem. The present effort aims to reveal the dynamics and relationships of the primary terrestrial influents, which means the fox and its animal foods, presumably the snowshoe hare, red squirrel, and woodland deermouse. At present, these must be regarded for the most part as potential food species, since the dependencies of the fox are still to be demonstrated.

Restricting the present project in this manner confines it largely to the food linkage of greatest significance other than that of the wolf, moose, and beaver, (already intensively studied). Species of probably minor influence are the long-talled weasel, muskrat, otter, several bats, and an unidentified cat. These will be related, as appropriate, to the rest of the community.

Red fox (Vulpes $\underline{\text { f. fulva (Desmarest)) }}$

The most logical approaches to studies of the fox appear to be through extensive collections of scats to reveal year-around food habits and through livetrapping and track counts to determine population levels. Work of the past year is chiefly significant as an index of which methods will be most rewarding on Isle Royale.

In the summer of 1966 a collection of 81 fecal speciuens was made from trails in representative parts of the island. Based on occurrence percentages, it was determined that primary foods in June and July were hare, squirrel, and mouse. In August and September the diet shifted almost entirely to berries and other fruits. It has been notzd in former years that wintering foxes utilize the fruits of mountain ash when these are available, but last winter this important food for foxes and birds was missing through a total fallure of the trees to bear. It was evident in February and March that a principal source of support for foxes was scavenging on moose killed by the wolves.

Fox numbers, 1966-67: In the Initial years of the Isle Royale investigations it was noted that foxes were frequently seen from the air in the course of flying for rolf observations and moose counts. Beginning in 1961, records of foxes seen on all flights were kept systematically during the seven weeks of winter field activity. Table 1 presents the record for this work as it now stands: 
Table 1. Foxes Seen in Winter Aerial Observations

\begin{tabular}{|c|c|c|c|c|}
\hline Observer & Year & $\begin{array}{l}\text { Foxes } \\
\text { observed }\end{array}$ & $\begin{array}{l}\text { Flight } \\
\text { hours }\end{array}$ & $\begin{array}{r}\text { Foxes p } \\
\text { flight }\end{array}$ \\
\hline $\begin{array}{l}\text { Mech } \\
\text { Shelton } \\
\text { Shelton } \\
\text { Jordan } \\
\text { Jordan } \\
\text { Jordan } \\
\text { Johnson }\end{array}$ & $\begin{array}{l}1961 \\
1962 \\
1963 \\
1964 \\
1965 \\
1966 \\
1967\end{array}$ & $\begin{array}{l}29 \\
45 \\
67 \\
39 \\
45 \\
28 \\
71\end{array}$ & $\begin{array}{l}135 \\
121 \\
129 \\
157 \\
140 \\
160 \\
169\end{array}$ & $\begin{array}{l}21.5 \\
37.2 \\
51.9 \\
23.2 \\
32.1 \\
17.5 \\
42.1\end{array}$ \\
\hline
\end{tabular}

The increase in foxes seen per 100 flying hours from 1961 to 1963 was correlated with, and probably lagged behind, a corresponding increase in hares. Since then, both hares and foxes have declined.

In an attempt to obtain another index of numbers for year-to-year comparisons, aerial track counts were begun during the past winter. In February, five lines were lald out, totalling $35.7 \mathrm{miles}$. These routes were flown during favorable weather and ground conditions at a helght of about 300 feet. Through the use of initial practice runs, certain "rules" of counting were adopted; for example, fox tracks separated by more than 100 yards were attributed to different animals. Table 2 gives information collected on nine flights.

\section{Table 2. Summary of Pox Track-Count Flights}

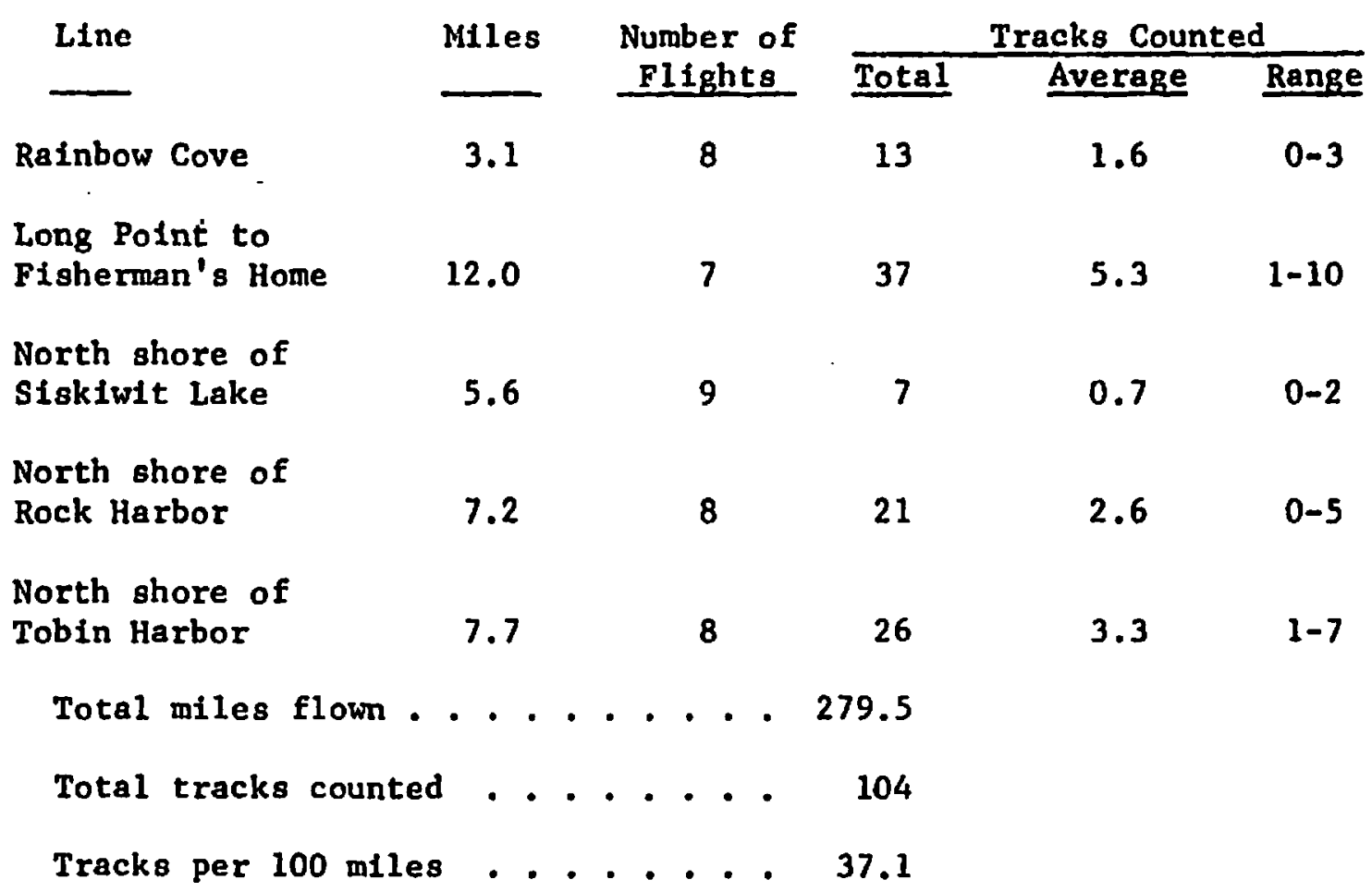


Conditions for aerial track counting are best when the air is calm and snow is not blowing. The optimum time is between $10 \mathrm{a.m}$. and $2 \mathrm{p} . \mathrm{m}$., when shadows are least strong. The day should be clear; overcast conditions with flat lighting are useless for this purpose, and tracks show poorly on fluffy snow. The greatest variable probably is the time elapsed since the last new snow, and this factor is being appraised as closely as possible.

Winter observations by aircraft also are used to determine the extent of activity in known denning areas, and several new sites of possible dens were located for checking during the spring rearing season.

Fox tagging: A for: tagging program was begun in February with two animals trapped in padded steel traps and tranguilized by the method devised by Balzer (1963, Jour. Wildl. Mgt. 29(3):438-442). Glen C. Sanderson, of the Illinois Natural History Survey, supplied an experimental quantity of the drug, "diazepan." Another fox was collected for necropsy. The pelage of these three animals was in prime condition, and no ticks or fleas were found. It probably will not be possible to handle foxes on a large scale, but a sufficient number should be caught or collected to gain basic biological information on the Isle Royale population.

Snowshoe hare (Lepus a. americanus Erxleben)

This hare piobably is the principal prey species of the fox on the island. Subjective observations of recent years indicate that it fluctuates in population level, although here the species evidently does not attain the excessive numbers that are reported for some northern environments. At present the snowshoe probably is at or near the low point of its "cycle."

Habitat preferences of this species will be surveyed by spring pellet counts on a system of plots established by Jordan for similar work on moose. A winter use index for both of these browsing species will be obtalned each year untll the value of such an approach can be appraised. Preliminary work was done during the past winter on a track-count index similar to that established for foxes. It is still questionable whether the hare track counting can be standardized sufficiently to be userul.

Hare live trapping

A more intensive study of hare populations from year to year will be carried out by a live-trapping and tagging program. An initial 8.26-acre grid of 33 National live traps was established in July 1966 on Raspberry Island, in the Rock Harbor chain of islands. The forest type is principally fir and birch. Hares were marked with numbered ear tags and examined for sex, weight, condition of pelage, ectoparasites, breeding status, and other biological information. The low density of hares at present probably is demonstrated by the fact that only nine animals were caught in three 5-day trapplng periods from July to September. Three juvenile hares were aged according to weight-gain and hind foot length (criteria supplied by lloyd $B$. Keith), and these individuals indicated littering in late June and again about the first of August. One juvenfle caught elsewhere was from a late-June litter. 
Red squirrel (Tamiasciurus hudsonicus regalis A. ․ㅡ. Howel1)

The Isle Royale red squirrel is recognized as a separate subspecies restricted to this island. Its numerical status and biology are being studied by a live-trapping program similar to that for the snowshoe hare. Two grids were laid out and trapped during the summer. Experimentation indicated that these traps should be opened shortly after dawn, then run at mid-day and 6 p.m. to minimize mortality. They are closed for the night. A peanut butter--rolled oats mixture proved to be an effective bait.

The first study area is 11 acres of cedar-alder swamp interspersed with ridges supporting white spruce, fir, and birch. In 48 traps operated during five perlods, 25 squirrels were taken and marked. Breeding evidently occurred in June and July, at which time nearly all adult males had scrotal testes.

A 36-trap grid in sugar maple--yellow birch forest was opened on August 6. This line was operated for one 5nday period, and six squirrels were tagged and released.

In March, 1967, a winter trapping quadrat was laid out on a 9-acre area southeast of the Windigo camp. The forest type is climax fir-spruce-birch. Among twelve squirrels taken, the sex ratio was equal, and four males had scrotal testes at this season.

An unusual circumstance relative to squirrel activity was observed after the opening of the winter camp on 2 February. In other years, periods of inactivity for several days had been noted, particularly at times of severe cold and wind. In 1967, no squirrels were observed in the immediate vicinity of the camp for the entire month of February, and few signs of this species were seen elsewhere. Our first impression was that the population had nearly died out-- logically, as a result of the marked shortage of seeds and fruits of woody plants during the past two winters (1965-66, 1966-67).

In March, however, this specles became active, and trapping was fairly successful, as described above. It appeared that the sustained inactivity was a result of the extraordinarily deep, fluffy snow that had been maintained by frequent additions during the month. The snow failed to pack becaúse of recurring temperatures well below zero (down to $-35^{\circ}$ ). This was the coldest Pebruary we have experienced in the nine years of the winter study. It is unquestionable that red squirrels would have found it difficult or impossible to travel under these conditions and would have been highly vulnerable to foxes.

During the past winter a beginning also was made on a "spot count" index, which can be used to compare squirrel densities in various habitat types sampled within given periods of the year. The method consists of recording the number of squirrels seen and heard in a sampling interval at a series of stations. The sugar maple--yelow birch forest, white spruce--balsam fir, the 1936 burn, and century-old burns (birch-aspen-conifer) will be compared.

Woodland deermouse (Peromyscus $\mathrm{m}$. mantculatus (Wegner))

The deermouse is the third potentially important prey animal of the fox that is being studied, in this case by live-trapping and snap-trapping. 
A livetrap grid of 4.65 acres has been located on the south-facing slope on Conglomerate Bay. It consists of 81 Longworth traps in 9 rows 50 feet apart. The bait is rolled oats. Preliminary indications are that this habitat supports a relatively high density of deermice, a species that can not be regarded as plentiful on the island as a whole. A complete vegetation analysis is being made of this trapping site.

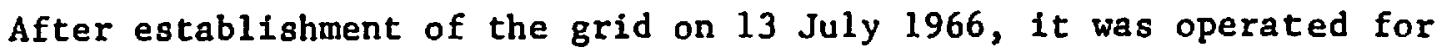
four 5-day periods from July through September. Since these animals are primarily nocturnal, traps were set in the evening and checked in early morning.

Present information does not indicate the full length of the breeding season. Pregnancies declined from July to August and were absent in September. A total of 17 mice were toe-clipped for future identification; two of these were parasitized by the larvae of a cuterebrid fly.

An adult female was held in captivity for nearly a month, and on 27 July gave birth to five young, all males. These immature mice were weaned naturally at 25 days and showed a daily weight gain of $.19 \mathrm{~g}$.

It is evident that a more extensive sampling of the deermouse population will be possible by the use of snap traps. Animals collected furnish information on biology and habits of the species. In the summer of 1966, a total of 20 stations were trapped for 3-day periods in various parts of the island, using 60 museum specials, for an aggregate of 3723 trap-nights. The catch was 128 mice. The number of animals taken per 100 trap-nights increased from 1.7 in June to 3.5 in July, 4.3 in August, and 9.7 in September, indicating a population buildup from spring to fall. An additional 25 mice were trapped in the vicinity of the research quarters.

Mice collected were examined relative to sex, age, weight, length, tail length, hindfoot length, ear length, pelt color, nipple size, vagina perforate or otherwise, symphasis pubis open or closed, pregnancy, location, position of testes, and parasitism. Age classes were determined on the basis of body weight: immature, less than 15; subadult, 17-17 g; adult, $17 \mathrm{~g}$ and over. All individuals showing signs of sexual maturity were $17 \mathrm{~g}$ or heavier. Findings relative to reproductive condition in the mice examined are summarized in Table 4. The records indicate a peak of breeding in June, with a gradual tapering off during the summer. The average number of empryos in 13 females was 5, ranging from 4 to 6 .

Table 4. Reproductive Condition of Trapped Deermice

\begin{tabular}{ccccc} 
& June & July & August & September \\
\cline { 2 - 3 } & 9 & 10 & 7 & 3 \\
Percent pregnant & 67 & 60 & 14 & 0 \\
Percent lactating & 0 & 20 & 14 & 0 \\
Number of adult males & 4 & 16 & 12 & 3 \\
$\begin{array}{c}\text { Percent with } \\
\text { scrotal testes }\end{array}$ & 75 & 44 & 8 & 0
\end{tabular}


Moose--Wolf Studies

As noted previously, winter field work began this year (1967) on 2 February and terminated on 21 March. This was the coldest winter period experienced in the nine years of our research; the mean maximum daily temperature for seven weeks was $19.6^{\circ} \mathrm{F}$. and the mean minimum $-4.9^{\circ} \mathrm{F}$. When the field party arrived on the island, snow depth at Windigo was approximately 23 inches. Because of the constant cold, it was unusually fluffy and difficult footing for both men and animals. By 21 February, the snow accumulation was 31 inches. Less than two Inches fell during the following four weeks, and the existing snow had settled to 25 inches by 21 March. It is our subjective judgment that moose were using lake edges (where snow was wind-packed) more than usual this winter. No moose were to be found in the higher ridges, although they were on the burn east of Sisk1wit Lake.

Winter weather was generally favorable to flying, and the total flight time with the light plane was 169 hoursm- a figure slightly higher than the average for previous years. In early February there were leads of open water between Isle Royale and the Canadian mainland. However, with temperatures consistantly below zero for the next ten days, the lake froze over to the north shore along the entire length of the island, and this ice was largely intact when winter operations were over. Likewise, around the south shore of Isle Royale and as far as could be seen to the south, ice was continuous for several days in the third week of February, and by the 24th only a few lanes of open water were to be seen near the island. This was more ice than had been seen previously in these studies. Such conditions permitted landings at usually inaccessible locations on the solid shelf ice.

Moose numbers and productivity

The winter field work included an aerial moose count employing a stratified sampling procedure. This program, designed by Jordan and Peter E. Dress (former departmental statistician), was used in 1966 and described in that annual report. To compensate for the irregular distribution of moose on Isle Royale and thus increase sampling efficiency, the island is divided into four strata of moose density, which are sampled separately.

Jordan's 1966 plots were laid out using landmarks anally recognizable from the air. Thus the same plots could be used, and 67 were counted ranging from .05 to .92 square miles. The total area sampled was 25.52 square miles, representing 12 percent of the island. Each plot lay within one of the four density strata, and extrapolation indicated the total population of the stratum, as shown in Table 5 .

Table 5. 1967 winter aerial census of moose

\begin{tabular}{|c|c|c|c|c|c|c|}
\hline Stratum & $\begin{array}{c}\text { Area } \\
(\mathrm{sq} \cdot \mathrm{mi} .) \\
\end{array}$ & Plots & $\begin{array}{l}\text { Percent of } \\
\text { stratum }\end{array}$ & $\begin{array}{c}\text { Moose } \\
\text { counted }\end{array}$ & $\begin{array}{l}\text { Moose per } \\
\text { sg. mi. }\end{array}$ & $\begin{array}{c}\text { Calculated } \\
\text { total }\end{array}$ \\
\hline 1 & 53.14 & 9 & 7.3 & 2 & 0.51 & 27 \\
\hline 2 & 53.45 & 12 & 10.5 & 7 & 1.27 & 67 \\
\hline 3 & 71.46 & 18 & 9.1 & 16 & 2.46 & 176 \\
\hline 4 & 35.70 & 28 & 26.9 & 70 & 7.29 & 260 \\
\hline I.R. & 212.75 & 67 & 12.0 & 95 & 2.88 & 530 \\
\hline
\end{tabular}


Applying 95 percent confidence limits to the population estimate of 530 places the actual population somewhere between 337 and 723 . This is about 25 percent lower than the 721 calculated for 1966. Limited information on moose productivity in the summer of 1966 does suggest a poor year for calf production (see below). In all such counting it seems reasonable to suppose that at least 10 percent of the animals actually on the plots are missed. Variance analyses revealed that the sampling error in all strata was not significantly different from that present in last year's calculations.

Information on herd composition and productivity in 1966 is fragmentary. The annual aerial survey could not be taken in fall, and the only available data on the calf crop are summer observations by Johnson and the two undergraduates (Table 6). These were largely incidental to other work and are principally from the northeast half of the island. The three sets of records were analyzed to eliminate possible overlap, and the results indicate that moose productivity probably was less than is considered average for Isle Royale. A ratio of less than 50 calves per 100 adult females was common to all three counts. Calves evidently comprised less than 20 precent of the entire population. Only one investigator reported twins, and only two sets were seen. This represents only 6 percent of the 33 females he observed accompanied by calves. No figures are avallable on calf survival in 1966.

The foregoing information is scant, but it does imply that moose productivity in 1966 may have been subnormal and that this partially accounts for the lower numbers of moose found in the winter census.

Table 6. Summer moose observations, 1966

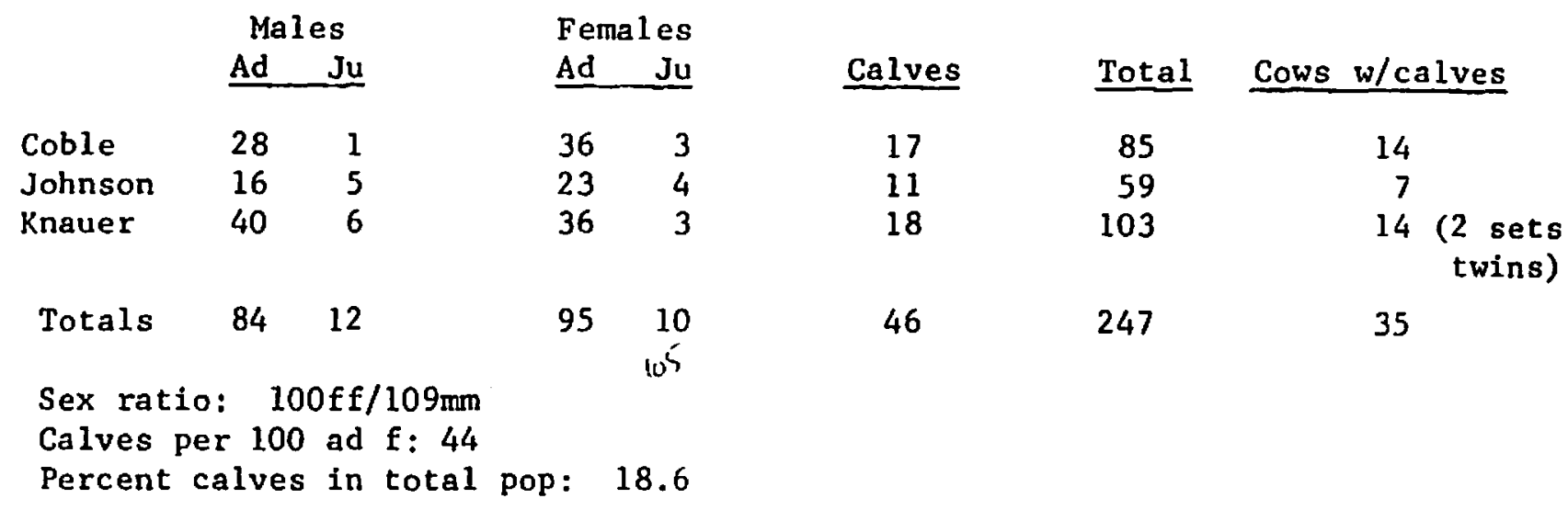

Sex, age, and condition of moose killed by wolves

The sites of all 12 known wolf-killed moose were investigated on the ground via snowshoe trips during the winter study, and the mandibles of 11 specimens were collected. Four of the moose were males, six were females and two were calves of unknown sex. Age determinations on the adult animals have been made by two different techniques. One is the usual wear-class method, described for moose by Passmore et al (in Peterson, 1955, N. A. Moose). In addition, all spectmens were aged for the first time this year by a new method, first described by $B$. L. Mitchell for red deer. It involves counting growth layers in dental cement. With the assistance of John $\mathrm{C}$. Olson, graduate student in wildlife biology, sections of the first lower molar tooth were prepared for each specimen. These were then ground and polished and the growth layers in the cement pad between the tooth roots were read under low power magnification (10X). 
Sections of the first molar tooth in an upper row also were prepared in the case of most of the adult animals; the number of annulations counted was then averaged with that obtained for the same tooth in the lower jaw. Table 7 presents a comparison of the results obtained by employing both techniques.

Sectioning of molar teeth will continue, in an effort to refine the technique and determine its limits of applicability. As can be seen from Table 7, the preliminary results are promising and indicate that the new technique will permit a more exact determination of age in moose than is possible by means of mandibular tooth wear criteria. If these indications are born out, we intend to re-age the entire collection of specimens acquired in the previous eight years of the project's existence.

Table 7. Comparison of ages determined from mandibular tooth wear criteria and from annulations in dental cement of Isle Royale moose

\begin{tabular}{|c|c|c|c|c|c|}
\hline \multirow[t]{2}{*}{$\begin{array}{l}\text { Specimen } \\
\text { number }\end{array}$} & \multicolumn{3}{|c|}{ Mandibular tooth wear } & \multirow[t]{2}{*}{$\begin{array}{l}\text { Cement } \\
\text { layers }\end{array}$} & \multirow[t]{2}{*}{$\begin{array}{l}\text { Estimated } \\
\text { age in years }\end{array}$} \\
\hline & $\begin{array}{l}\text { Wear } \\
\text { class }\end{array}$ & $\begin{array}{c}\text { Known range of wear } \\
\text { Method } 1 /\end{array}$ & $\begin{array}{l}\text { class in years } \\
\text { Method } 2 /\end{array}$ & & \\
\hline 380 & IX & $12-20$ & - & 15 & 15 \\
\hline 382 & VIII & $10 \frac{1}{2}-15 \frac{1}{2}$ & - & 11 & 11 \\
\hline $383 *$ & II & $2 \frac{1}{2}$ & $2-3$ & 3 & $2 \frac{1}{2}$ \\
\hline 384 & VIII & $10 \frac{1}{2}-15 \frac{1}{2}$ & -- & 13 & 13 \\
\hline 385 & calf & - & $\cdots$ & 1 & 9 months \\
\hline 386 & IX & $12-20$ & -- & 14 & 14 \\
\hline 387 & IX & $12-20$ & -- & 15 & 15 \\
\hline 388 & VII & $8 \frac{1}{2}-10 \frac{1}{2}$ & $10-17$ & 9 & 9 \\
\hline 389 & VIII & $10 \frac{x}{2}-15 \frac{1}{2}$ & -- & 14 & 14 \\
\hline 390 & IX & $12-20$ & -- & 13 & 13 \\
\hline $391 *$ & II & $2 \frac{1}{2}$ & $2-3$ & 3 & $2 \frac{1}{2}$ \\
\hline 392 & VI & $6 \frac{1}{2}-8 \frac{1}{2}$ & $8-15$ & 8 & 8 \\
\hline 393 & IV & $4 \frac{1}{2}$ & $4-7$ & 5 & 5 \\
\hline
\end{tabular}

1/ after Passmore et al (1955. In Peterson, North American moose).

$\frac{1}{2} /$ after Sergeant and Pimlott (1959. Jour. Wildl. Mgt. 23)

* indicates autopsy specimen not killed by wolves

On the basis of data presented in Table 7, the mean age of 10 adult moose killed by wolves during the 1966-67 winter was calculated to be 11.6 years. Bone specimens were recovered wherever possible from these specimens for quantitative analyses of fat content of the marrow. Elwyn Schall of the Biochemistry Department at Purdue University is currently performing these tests and results will be forthcoming in the next annual report. Since olson (1966, unpublished report) has detected a consistent variation in the fat content of bone marrow between the proximal and distal bones of a leg, samples were taken whenever possible from each of the major bones of both a fore and a hind leg. Using rough visual and tactual criteria for judging the condition of bone marrow revealed that six of the eleven specimens examined had some degree of fat depletion. 
Moderately advanced necrosis of the jaw was found in three of the moose examined. One of these, an old bull killed by two wolves in the vicinity of Thomsonite Beach, was autopsied before the wolves had consumed the internal organs. This animal's lungs were heavily infested with cysts of the hydatid tapeworm (Echinococcus granulosus). One lung alone contained at least 40 such cysts, some of which were 1 to 1.5 inches in diameter... Macro-examination of the liver, however, disclosed no visible cysts. A day after it was killed the stillunfrozen viscera of this animal were discolored by advanced decomposition, suggesting possible peritonitis before death.

\section{Condition and pathology of moose killed by non-predatory causes}

Two moose were shot for autopsy purposes during the 1967 winter study.

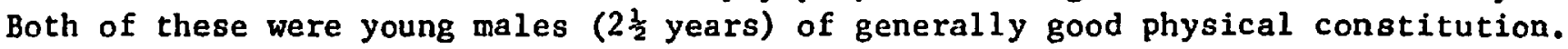
Subcutaneous, adrenal and visceral fat reserves showed little sign of depletion in either animal, but certain pathological findings were common to both specimens. Among these was a locally heavy infestation of winter ticks (Dermacentor albipictus). In the case of one animal (非91), as many as 17 adult ticks per square inch were found on areas of the belly. The larval stages of this parasite also were present.

Tick infestation appeared to be quite prevalent throughout the entire Isle Royale moose population this winter. A conservative estimate of 20-25 percent of the animals seen from the air had large bare spots, obtained as the result of rubbing in response to the irritation caused by this and possibly .. other skin parasites. In two cases, an emaciated cow showing extensive halrless areas over the body was observed staying closely by the side of a healthy cow-. as if for protection. In both observations the afflicted cow was originally mistaken for a calf, on a basis of size and behavior.

Tapeworm,cysts were present in both of the moose autopsied. The lungs of specimen $\$ 383$ contained no visible cysts and those located in the liver were still quite minute in size. However, four well developed cysts were found in each lung of moose $\$ 391$. The largest of five additional cysts in this animal's liver measured $1 \frac{1}{4}$ inches in diameter. These findings suggest that cysts of the hydat1d tapeworm may be of consequence to Isle Royale moose at an even earlier age than was previously suspected.

Wolf numbers, winter 1967

The largest number of wolves actually accounted for on any single day was 19. This total was found on at least two separate occasions. Since all these animals were observed on the northeast sector of the island, and at least two lone wolves were known to be frequenting the extreme southwest end at that time, it can be said that the 1967 winter population comprised at least 21 animals. Actually this estimate is conservative, because it does not include unaccounted-for single wolves and/or pairs possibly occurring on other parts of the island. A more realistic estimate of the total population would be 23-25 wolves.

As in previous years, a major objective of the 1967 winter research was to investigate wolf numbers, behavior, social structure, and patterns of predation. This year, wolf movements and k11ls were fairly well documented during the first weeks of the study. The previously mentioned lack of new snow throughnut the latter half of the seven-week period complicated wolf tracking considerably, 
since distinguishing between fresh and older tracks became progressively more difficult. Under these conditions, pilot Murray's skill and experience in this work proved to be the project's most valuable asset.

Wolf aggregations and movements

In contrast to other years, the wolves' social structure this winter was not characterized by a single large and dominant pack, but rather by several smaller loosely knit social groupings with poorly defined and overlapping territories. In 1965 and 1966 Jordan noted certain distinct behavioral changes within the large pack, which he attribited to a change in the role of the dominant male wolf. He also recorded the death, in March 1966, of a mature wolf assumed to be the alpha male and documented further changes in the large pack's behavior. observations this year suggest a continuation of these trends, resulting in the actual breakup of the large pack in 1966. As of the past winter, a stable reorganization of this pack had not taken place, and the social structure of the island's wolf population otill spjeciced to be in a state of flux. This might be ascribed in part to the absence of the lead male wolf.

The "six pack": During most of the month of February it was possible to distinguish at least four fairly well defined wolf aggregations on the island. One of these was a pack of six wolves, first seen on 5 February on $a$ kill at Lake Theresa. These were subsequently observed at the site of this kill and on 6 and 7 February, but were gone from there by 9 February. The next kill associated with this group was at Sargent Lake, where six wolves were sighted on 16 February. The relative proximity of the two sites suggests that both kills had been made by this pack.

The pack of six left the Sargeant Lake kill on 21 February. Their tracks led to Saginaw Point and then to Scoville Point along the outer edge of the northeast peripheral islands. At that point the tracks were no longer visible from the air but were picked up again on the same day off Blake's Point. The tracks went around the northeast extremity of the island to Locke Point, where six wolves were seen. This marked the last positive observation of the pack of six identifiable as such this winter.

The "Lily Lake seven": Another pack, of seven wolves, contained a "marked" animal. This individual was distinguishable by an overall lighter coloration of its shoulders and an unusually light chevron on its back. The pack was seen for the first time on 17 February on a kill in the vicinity of Lily Lake. An earlier kill in the Siskiwit Swamp may also be attributed to this group, but it was taken over by a single wolf after the pack's departure. The pack left the Lily Lake kill on 22 February and traveled through the Siskiwit Swamp. On the following day, we followed their progress from Lake Halloran along the north shore of Siskiwit Bay to Point Hay, During the night they continued in the same direction, and six wolves were found resting at Lake Theresa on the morning of 24 February. It is prpiogile that one wolf dropped off at some time during this interval, because from then on the pack never comprised more than six wolves. In fact it had been noted on the previous day that one of the seven wolves was lagging some distance behind and started off saveral times in a direction opposite to that taken by the rest of the pack.

The remaining six wolves resumed traveling again on 24 February and continued in a general northeasterly direction. Following essentially the same route described above for the pack of six. They were seen that afternoon off Raspberry Island and again on the following day at the mouth of Tobin Harbor off 
Scoville Point. They then traveled west the length of Tobin Harbor and were observed on the morning of 26 February at the head of Moskey Basin. On the same afternoon they wounded a moose on Saginaw Point but did not kill it until the night of 1 March. Thus, in the seven-day period since leaving the Lily Lake kill, the pack had traversed a total distance of 57 miles.

The "Tobin Harbor foursome": A third association, of four wolves, probably was responsible for two kills, both in the Tobin Harbor area. These kills, both cows, were confirmed on 13 February and 3 March respectively. However, in the case of the second kill, it is difficult to say positively if this group did actually kill the moose, because they were never seen at the site of the kill. The Tobin Harbor pack seemed to be a loose grouping and frequently was observed as two separate pairs.

The "Siskiwit lake duo": The final known wolf aggregation was a group of two, which confined its activities to the central sector of the island. These were recognizable by the fact that the smaller of the two (presumably a female) was shy of the plane. At least two kills can be attributed to this group. The first of these, a calf, at the southeast end of Siskiwit Lake. The two wolves were first seen here on 12 February and again on three subsequent days. They made their next kill eight miles to the west on 22 February not far from Thomsonite Beach and were observed there regularly until 5 March.

The "black pack": The most notewortby event of this year's winter study occurred on the morning of 25 February, when a pack of seven wolves, including four black animals, was seen lying on the ice of Amygdaloid Channel. Observations made later that day and on several days thereafter revealed that this group was feeding on a kill at Lake Ahmik. The kill itself was already a few days old and had been confirmed on 24 February, when six wolves were seen there. None of these animals appeared unusually dark that day, but since both the kill and the wolves were in the woods, it is impossible to say with certainty that they were not the same animals observed in the open there on the days following. In fact it seems probable that the pack in question was responsible for this $\mathrm{k} 111$.

The black pack's unexpected appearance represents the first recorded incidence of black wolves on the island and poses questions as to the pack's origin and identity. It is possible that these wolves are immigrant animals, which came to Isle Royale from the Canadian mainland via the Lake Superior ice. At least two separate observations of injured wolves immediately prior to and on the day of the "black" pack's discovery could be construed as indications of fighting between a pack of newcomers and some of the island's resident wolves. On 24 February an apparently dead wolf was observed lying in a bloody bed approximately a quarter-mile north of the Rock Harbor Lodge. Efforts to retrieve this animal the following day revealed that it was still living and quite mobile.

On the morning of 25 February another injured wolf, with a bloody head, was seen not far from the new pack of seven on Amygdaloid Channel. He was traveling fast across the ice away from Isle Royale and toward Canada.

As a further indication of social troubles among the wolves, on the afternoon of 2 March we found blood stains in the imnediate vicinity of the Rock Harbor Lodge. Investigation disclosed a large bloody bed, where an injured wolf had evidently been lying when disturbed by our landing. A few minutes later a wolf was seen on the ice of Rock Harbor. We took off again and followed it for about half a mile along the north shore of the harbor. The wolf had an injured 
left foreleg and was limping markedly. It went ashore and lay down on the top of a small ridge approximately 100 yards from the shoreline. It was seen at the same location the next morning but was not there that afternoon. "The site and surrounding area were searched thoroughly but the wolf could not be found. Blood stains were present only where the wolf had been lying. The animal's tracks led north in the direction of Tobin Harbor. It is quite possible that this was the same wolf seen in Rock Harbor a few days earlier.

Most of the evidence supports an hypothesis that the "black" pack is a part of the island's 1966 pre-winter wolf population. The wolves' behavior indicated that they had no fear of the aircraft. This would seem improbable had the pack come from the Sibley Peninsula in Canada, where it would have been exposed to hunting from an airplane.

Since melanistic coloration in wolves is inherited recessively, it is possible that the black animals represent last year's reproduction among the island's population. Observations and photographs substantiate this hypothesis in that at least two of the four showed pup-like characteristics. However, our criteria for discriminating between pups and mature wolves from the air are not infallible and errors are easily possible. Assuming that all the black wolves are immature individuals would, of course, imply a high survival in a single litter.

A further question is whether or not the black pack is identical with the pack of six, last seen two days earlier off Locke Point. The spatial and temporal proximity of the two observations and the apparent "disappearance" of the pack of six with the advent of the "black" pack supports this interpretation. Furthermore, the total wolves seen on any one day subsequent to the discovery of the black wolves never suggested the presence of an additional wolf aggregation on the island.

Observations made on 3 March afford the most conclusive evidence that the black pack did comprise a part of the pre-winter Isle Royale wolf population. On that afternoon a total of eleven wolves were seen at the site of the Saginaw Point kill. Eight of these, including the four black animals, were resting together in the immediate vicinity of the kill; the remaining three were lying approximately 500 yards away from the main group. There were no indications of any fighting among these wolves. This was confirmed by later investigation of the kill site on the ground. These facts suggest strongly that the black pack had joined and fraternized with the other wolves, already occupying the kill.

Subsequent observations witnessed an apparent dispersion of both packs. Neither of the two groups was present at the kill by the next morning, and the Lily lake pack was not seen again as a unit for the remainder of the study. The black pack returned to the north shore of the 1sland, largely via the route it had taken to get to the Saginaw Point kill. It was last seen in its full compliment of seven wolves on 5 March off Round Island. After that the pack evidently split into two smaller associations. One of these, consisting of two gray and two black wolves, frequented the northeast end of the island and was observed on various occasions in the Rock and Tobin Harbor area. Another group of three wolves, one of which was black, was seen on 15 March far to the west near Sugar Mountain and again two days later on the ice of Grace Harbor. This leaves one black individual unaccounted for and implies that an additional gray wolf had joined one of the two groups. The breakup of the black wolves into two groups might seem to contradict the assumption that all the darker individuals represent pups of the same litter. On the other hand, the alignment of one of the resulting groups with an additional gray wolf lends further support to the hypothesis that the original black pack was present on Isle Royale prior to this past winter. 
An apparent shift in the center of wolf activity from the northeast to the southwest end of the island followed the disintegration of the Lily Lake group and the black pack. This trend was especially evident during the final week of the winter study.

It is evident from the foregoing that the problems encountered this past winter in documenting wolf activities and social parameters were more complex than those of other years. No final conclusions can be drawn on the basis of this year's data alone, and the explanations offered above are largely speculative. In view of these circumstances and the prevalling ouboptimal tracking conditions, the use of radio-telemetry might have increased the efficiency of our efforts considerably. Its possible application in future years of wolf studies on Isle Royale are to be investigated.

The remains of three wolf-killed beavers and numerous observations of wolf diggings at beaver colonies indicated a possibly increased attention to this food supply by wolves during the past winter. This seemed eapecially true of individual wolves or smaller aggregations, which are obviously less efficient in killing moose.

\section{The Three-year Plan}

Tentatively, the present phase of the Isle Royale research program on mammal populations is expected to continue through June, 1969. The year 1968-69 will be one of sabbatical leave for $D$. L. Allen, when nearly full time can be devoted to this study. A particular effort will be made to fill in the pattern of field work in seasons which are not well represented in the program-- late fall and early spring. It should then be possible to bring together in a book the wildlife story of Isle Royale featuring the wolf, moose, and beaver, for a 12-year period.

With Jordan now at Yale, a part of the present plan is for him to continue measurement of the moose population through the pellet-group plots laid out during his tenure on this project and described in the 1965 annual report. A principal unknown in this part of the work is the defecation rate of Isle Royale moose in winter, which must be ascertained before the counts can be calibrated reliably.

In these investigations every effort has been made to avoid interference with the habits and social life of the wolves. Work elsewhere (notably Algonquin Park) now suggests strongly that the trapping and marking by radio telemetry of a wolf in each group would not disrupt their natural activity. During the coming year the possibility of doing this in winter and monitoring by aircraft will be investigated. Periods of unfavorable weather now cause the various packs to be "lost" for many days when they are localized in heavy cover on a kill. A means of locating them would greatly expedite the work. 